\title{
KIAA1549/BRAF Fusion Gene
}

National Cancer Institute

\section{Source}

National Cancer Institute. KIAA1549/BRAF Fusion Gene. NCI Thesaurus. Code C99843.

A fusion gene that results from a tandem duplication of approximately $2 \mathrm{Mb}$ at $7 \mathrm{q} 34$

which fuses exon 15 or 16 of the KIAA1549 gene to exon 9 or 11 of the BRAF gene. This fusion is associated with pilocytic astrocytoma. 